\title{
Impact of Salinity Stress on Germination of Water Spinach (Ipomoea aquatica)
}

\author{
Mohd Hafiz Ibrahim $^{1^{*}}$, Nur Azira Abas ${ }^{1}$ and Syeda Massoma Zahra ${ }^{1}$ \\ ${ }^{1}$ Department of Biology, Faculty of Science, Universiti Putra Malaysia, 43400 Serdang, Selangor, \\ Malaysia.
}

Authors' contributions

This work was carried out in collaboration among all authors. Author NAA designed the study, performed the statistical analysis, wrote the protocol and wrote the first draft of the manuscript. Author MHI managed the analyses of the study. Author SMZ managed the literature searches. All authors read and approved the final manuscript.

Article Information

DOI: $10.9734 / A R R B / 2019 / v 31 i 530060$

Editor(s):

(1) Dr. George Perry, Dean and Professor of Biology, University of Texas at San Antonio, USA.

Reviewers:

(1) Koksal Aydinşakir, Batı Akdeniz Agricultural Research Institute, Turkey. (2) Saleh Ahmed Shahriar, Sher-e-Bangla Agricultural University, Bangladesh. Complete Peer review History: http://www.sdiarticle3.com/review-history/47891

Original Research Article

Received 24 December 2018

Accepted 03 March 2019

Published 27 April 2019

\begin{abstract}
Aims: Salinity is one of the major abiotic stress that negatively affects plant growth in germination and early seedling stages. Salinity has becoming a serious problem as most of the parts of worldwide lands were affected by high salt concentration. Therefore, the effects of salinity ranging from $0 \mathrm{mM}, 25 \mathrm{mM}, 50 \mathrm{mM}$ and $75 \mathrm{mM}$ Sodium chloride $(\mathrm{NaCl})$ concentrations on germination and early seedling growth of water spinach and their salt tolerance mechanism.

Study Design: Completely Randomized Design (CRD).

Place and Duration of Study: This study was conducted at Tissue Culture Laboratory, Department of Biology, Faculty of Science in University Putra Malaysia (UPM) from June to August, 2018.

Methodology: In order to study the effects of salinity on water spinach, several parameters have been taken into account for measurement which include water uptake percentage, germination percentage, germination index, mean germination time, relative injury rate, seed vigor, seedling height reduction, hypocotyl and radicle length, seedling biomass, salt tolerance, total phenolic content and total flavonoids contents.
\end{abstract}

*Corresponding author: E-mail: mhafizphd@gmail.com, mhafizphd@gmail.com, mhafiz_ibrahim@upm.edu.my; 
Results: The results obtained showed that salinity adversely reduced water uptake efficiency, seed vigor, hypocotyl and radicle length, total phenolic content and total flavonoids content of water spinach. The seedling height reduction of water spinach increased significantly in relative to increasing salinity. However, seeds treated in mild salt concentration at $25 \mathrm{mM}$ of $\mathrm{NaCl}$ showed an increment of germination percentage and germination index.

Conclusion: Salt tolerance of water spinach increased as the response towards increasing salinity.

Keywords: Salinity; germination; total flavonoids; phenolic content; salt tolerance.

\section{INTRODUCTION}

Ipomoea aquatica or its common name called water spinach belongs to the family Convolvulaceae. It is an aquatic vascular plant that grows wild and commonly cultivated in Southeast Asia, India and Southern China [1]. Water spinach generally found on moist soil along the margins of fresh water, marshes, ditches and wet rice fields [2]. Ipomoea aquatica is a trailing or floating herbaceous plant with long and hollow stem occupied with large number of air passages and rooting at the nodes [3]. Water spinach is restricted to the tropics and subtropics thus does not grow well if the mean temperature is below $24^{\circ} \mathrm{C}$ [4].

Water spinach which also known as kangkong is commonly used to treat fever, bronchitis, constipation and liver complaints in Unani. While in Ayurveda, this plant is effective to treat jaundice and nervous debility. Furthermore, the leaf extract of water spinach is useful to reduce blood sugar levels [5]. Ipomoea aquatica consists of high nutritional values with substantial amount of amino acids, non-essential amino acids, macro salts, micro salts, crude fibers, carbohydrates, fatty acids, organic acids and polyphenols [6]. These components are a WHOrecommended pattern for an ideal dietary protein and potentially as food supplement as it comparable to conventional foodstuffs like soybean or egg.

Abiotic stress such as drought and salinity greatly influence plant growth and crop productivity worldwide [7]. A significant part of the world's land area is considered salt-affected by salinity or sodicity. The presence of salinity is mostly natural. Unfortunately, cultivation in agriculture has made a huge amount of land to become saline due to land reclamation or irrigation [8]. Munns (2005) stated that irrigated land composed of $15 \%$ of total cultivated land. Tanji and Wallender estimated that $23 \%$ of cultivated lands could be affected by salinity [9]. According to Rengasamy (2002), salts arise from weathering of rocks or aerial deposition of ocean aerosols through wind or rain contributes to salinity [10]. The main salt in the saline soils generally $\mathrm{NaCl}$ however there are also other significant concentrations of $\mathrm{Ca}^{2+}, \mathrm{Mg}^{2+}, \mathrm{SO}_{4}{ }^{2-}$ and $\mathrm{CO}_{3}{ }^{2-}[8]$.

Salinity may bring adverse effects by limiting the plant growth when salts accumulated in the root zone [11]. Salt stress causes detrimental effects in most major processes including germination, growth, photosynthetic pigments and yield [12]. Salt stress also being a factor of delayed seed germination and final germination percentage. It affects germination and seedling growth by creating osmotic pressure which prevents water uptake or by toxic effects of sodium $\left(\mathrm{Na}^{+}\right)$and chloride $\left(\mathrm{Cl}^{-}\right)$ ions [13]. Seed germination is the fundamental and vital phase of a plant's growth cycle as it determines the yield. Researcher stated that salinity adversely affects germination process in various plants such as Posidonia, Oryza sativa, Triticum aestivum, Brassica sp. and Zea mays [14]. According to Gul and co-worker's salinity changes the imbibition of water by seeds due to lower osmotic potential of germination media [15]. Furthermore, salinity induces toxicity which alters the enzymes activities of nucleic acid metabolism, alters protein metabolism and disturbs the hormonal balance in the seeds [16].

\section{MATERIALS AND METHODS}

\subsection{Seed Sterilization}

Seeds of water spinach (Ipomoea aquatica) were obtained from Green World Sri Serdang, Selangor. Seed sterilization was conducted according to a method reported by Hassen [17]. Seeds of water spinach were surface sterilized for 20 minutes in $5 \%$ of Sodium hypochlorite $(\mathrm{NaOCl})$. Then, the seeds were rinsed 3 times with distilled water for 2 minutes. 


\subsection{Preparation of Saline Solution}

Three different concentration of Sodium chloride $(\mathrm{NaCl})$ were prepared separately from $25 \mathrm{mM}, 50$ $\mathrm{mM}$ and $75 \mathrm{mM}$. Deionized distilled water was used as a control.

\subsection{Experimental Design}

Ten sterilized seeds were transferred into sterile petri dishes $(9 \mathrm{~cm}$ diameter) that have been layered with one piece of Whatman filter paper no. 1 containing $5 \mathrm{ml}$ of deionized distilled water (for control) or $5 \mathrm{ml}$ of different concentration of $\mathrm{NaCl}$ solutions including $25 \mathrm{mM}, 50 \mathrm{mM}$ and 75 $\mathrm{mM}$. The experiment was arranged in a completely randomized design (CRD) with five replicates per treatment for three cycles [18]. The petri dishes were sealed with parafilm to avoid evaporation and the seeds were left to germinate at room temperature of $25 \pm 1^{\circ} \mathrm{C}$.

\subsection{Observation}

Number of germinated seeds was recorded daily during 10 days for each cycle. Seeds were considered germinated as soon as the roots protruded $2 \mathrm{~mm}$ through the pericarp [19]. The seedlings of water spinach were retained for measurements of hypocotyl length, radicle length, fresh weight and dry weight at the end of the experiment.

\subsection{Data Collection}

\subsubsection{Water uptake percentage}

The percentage of water uptake by the seeds sown were calculated according to the formula [20]

WUP $=[($ Seed fresh weight - Seed dry weight) / Seed fresh weight] x 100

\subsubsection{Germination percentage}

Germination percentage of seeds were calculated after 10 days by using the following equation [21]

$\mathrm{GP}=$ (Number of germinated seeds / Total number of seeds sown) $\times 100$

\subsubsection{Germination index}

Germination index (GI) of seeds were calculated using the equation [22]
$\mathrm{GI}=\sum$ (Number of germinated seed / Days of last count)

\subsubsection{Mean germination time}

Mean germination time is calculated according to equation [17]

$$
\text { Mean germination time }(\mathrm{MGT})=\sum \mathrm{Dn} / \sum \mathrm{n}
$$

Where, $\mathrm{n}$ is the number of seeds which were germinated on day $D$, and $D$ is the number of days counted from the beginning of germination.

\subsubsection{Relative injury rate}

Relative injury rate was calculated according to a formula reported by Tsegay and Gebreslassie (2014) as the difference between germination percentage in control and germination percentage in salt treated seeds divided by the germination percentage in control [23].

$\mathrm{RIR}=$ (Germination percentage in control Germination percentage in salt treated seeds) / Germination percentage in control

\subsubsection{Seed vigor}

Seed vigor was calculated based on following equation [22]

Seed Vigor $=[($ Length of radical + length of hypocotyl) / 100] x GP

\subsubsection{Seedling height reduction}

Seedling height reduction (SHR) is defined as the delay in root length and shoot length expressed in percentage and calculated using the equation [24].

$$
\begin{aligned}
\text { SHR }= & {[(\text { Plant height in control }- \text { Plant height }} \\
& \text { in salt treatment }) / \text { Plant height in } \\
& \text { control }] \times 100
\end{aligned}
$$

Table 1. Preparation of saline solution

\begin{tabular}{lll}
\hline $\begin{array}{l}\text { Treatment } \\
(\mathbf{m M})\end{array}$ & $\begin{array}{l}\text { Amount of } \\
\mathbf{N a C l}(\mathbf{g})\end{array}$ & $\begin{array}{l}\text { Amount of } \\
\text { Distilled } \\
\text { Water }(\mathbf{m L})\end{array}$ \\
\hline 0 & 0 & 1000 \\
25 & 1.46 & 1000 \\
50 & 2.92 & 1000 \\
75 & 4.38 & 1000 \\
\hline
\end{tabular}




\subsubsection{Seedlings biomass}

The seedlings biomass was weighed by using analytical balance after dried in circulating oven at $80^{\circ} \mathrm{C}$ for 24 hours in order to standardize the mass [25].

\subsubsection{Salt tolerance}

The salt tolerance (ST) rate was calculated using the standard formula as follows [26]

ST $=$ (Seedling dry weight in salt treatment / Seedling dry weight in control) $\times 100$

\subsubsection{Total phenolic content}

Total phenolic content in water spinach were determined by using Folin-Ciocalteau reagent based on the method using a gallic acid as a standard phenolic compound [27]. About $1.0 \mathrm{~mL}$ of aqueous extract solution containing $1.0 \mathrm{~g}$ extract was diluted with $46 \mathrm{~mL}$ distilled water in a volumetric flask. Then, $1.0 \mathrm{~mL}$ of FolinCiocalteau reagent was added and mixed thoroughly. Three minutes later, $3.0 \mathrm{~mL}$ of $2 \%$ sodium carbonate was added and the mixture was allowed to stand for three hours with sporadic shaking. The absorbance of the blue color that developed was measured at $760 \mathrm{~nm}$ by using spectrophotometer. The concentration of phenolic was expressed as $\mathrm{mg} / \mathrm{g}$ of dry extract. The amount of total phenolics was calculated as gallic acid equivalents (GAE) from the calibration curve obtained from gallic acid standard solution and expressed as $\mathrm{mg} \mathrm{GAE} / \mathrm{g}$ dry weight.

\subsubsection{Total flavonoids content}

Total flavonoid contents in water spinach were determined by using the calorimetric method with slight modification [28]. In brief, $100 \mu \mathrm{L}$ of aqueous seed extract or standard solution was mixed with $400 \mu \mathrm{L}$ of ethanol and followed by the addition of the same volume of $2 \% \mathrm{AlCl}_{3}$ solution diluted in ethanol. The mixture was incubated for an hour at room temperature. Then, the absorbance was measured at $517 \mathrm{~nm}$. Rutin was used to plot the standard curve and the results were expressed as the mean in $\mathrm{mg}$ of rutin equivalents per gram of plant material from triplicate extracts (mg rutin/g dry weight).

\subsection{Data Analysis}

Statistical analysis was analysed using SPSS Window Version 24. One-way analysis of variance (ANOVA) was used to determine the significance difference among treatments followed by Duncan's Multiple Range Test $(\mathrm{DMRT})$ at $\mathrm{p}<0.05$ for mean comparison.

\section{RESULTS AND DISCUSSION}

\subsection{Effect of Salinity on Water Uptake Percentage of Water Spinach Seeds}

Table 2 shows that the water uptake percentage of water spinach seeds under all salt treatments were inversely related with $\mathrm{NaCl}$ concentration level. The result indicates that the water uptake percentage of water spinach reduced significantly $(p<0.05)$ at $75 \mathrm{mM}$. Seeds treated under both $25 \mathrm{mM}$ and $50 \mathrm{mM} \mathrm{NaCl}$ solution showed no significant difference as compared with control. As salinity level increases, the water uptake percentage of water spinach decreases gradually. Soils containing excess sodium chloride limits the plant available water which results in dehydration of the cell cytoplasm [29]. The entry of water into the seeds is profoundly influenced by the nature of seed coat. The water uptake percentage of water spinach decreases as the salinity level increases. Researchers stated that water uptake imbalance limits the hydrolysis of food reserve and cause immobilization of food reserve from storage tissue to developing embryo [30]. The result obtained is similar to the findings from salinity study of bean and rice [31,32]. Water absorption in cell differentiation and cell division is reduced due to salt stress that eventually lead to osmotic pressure. The concentration of soluble salts with their respectively high osmotic pressures affect plant growth by inhibiting water uptake in the roots [33]. So it can concluded that enhanced in salinity stress reduced the water uptake in water spinach.

\subsection{Effect of Salinity on Germination Percentage}

Seed germination is a crucial and most salt-sensitive plant growth stage that severely affected by increasing salinity. Seed germination begins from the imbibition of dry seeds. The imbibition of seed germination by salinity stress usually followed by toxic ion effects, water uptake deficiency and decreases in nutrient mobilization [34]. In present study, the effects of different $\mathrm{NaCl}$ concentrations on seed germination and early seedling growth of Ipomoea aquatica were compared. The 
result shows that there were no statistically significant difference at $(p<0.05)$ on germination percentage of water spinach seeds under different salinity levels as shown in Table 2. Seeds of water spinach germinated the most under very mild salinity level at $25 \mathrm{mM}$ whereas the least germinated seeds were under $75 \mathrm{mM}$ of $\mathrm{NaCl}$ solution. The germination percentage of the water spinach seeds were slightly decreased along with increasing salinity level. Seeds treated in control treatment has less germination percentage compared to seeds treated in very mild concentration at $25 \mathrm{mM} \mathrm{NaCl}$ solution. Higher salinity level at $50 \mathrm{mM}$ and $75 \mathrm{mM}$ decrease the amount of germinated seeds. Thus, it was observed that the seeds required longer time to germinate as high salinity delayed seed germination. Salt stress restricts water absorption by the seeds and consequently decrease the total germination percentage [35]. decrease in seed germination under salinity stress is due to physicochemical effects or by osmotic-toxic salts that exist in saline conditions [36]. Furthermore, the high concentrations of $\mathrm{Na}^{+}$and $\mathrm{Cl}^{-}$in the environment delay the seed germination by inducing toxicity in seeds [37]. In present study, seeds of water spinach showed no significant difference in germination percentage. However, seeds treated under $25 \mathrm{mM}$ $\mathrm{NaCl}$ solution had a slight increment in germination percentage as compared to control. This result agrees with previous studies reported on the halophytes Salicornia europaea and Suaeda maritima and New Zealand spinach where low levels of salt treatment improved plant growth [38] [39].

\subsection{Effect of Salinity on Germination Index}

Germination index are used to indicate the uniformity and speed of the seed germination as proposed by Deinlein et al. (2014). The result shows that the germination index of water spinach under different salinity were not significantly difference at $(p<0.05)$. The highest germination index was the seeds treated under $25 \mathrm{mM} \mathrm{NaCl}$ solution while the lowest was seeds treated under $75 \mathrm{mM} \mathrm{NaCl}$ solution as shown in Table 2. The germination index reflects the germination percentage on each day along the germination period. Higher germination index values indicate higher and faster germination [40]. Mean germination time and germination index could lead to an enhancement in the salt tolerance during germination phase. The present findings showed no significant difference in germination index of water spinach seeds. Seeds treated under low salinity level (25 $\mathrm{mM} \mathrm{NaCl})$ has higher germination index as compared to control. Increment in germination index values indicates the decline in phytotoxicity and eventually more mature germinated seeds [41]. Whereas seeds treated under higher salinity levels $(50 \mathrm{mM}$ and $75 \mathrm{mM} \mathrm{NaCl}$ ) showed a decline in germination index. This result is aligning with the findings in maize that showed decreased germination index at higher salt concentrations [42].

\subsection{Effect of Salinity on Mean Germination Time}

The result shows that the mean germination time of water spinach under different salinity level were significantly difference at $(p<0.05)$. Seeds treated under control treatment possess the highest mean germination time whereas seeds treated in $75 \mathrm{mM} \mathrm{NaCl}$ solution possess the lowest mean germination time. The time it takes for the seeds to germinate decreases along with increasing salinity level as shown in Table 2. Mean germination time is considered as mean of the lag period for all seeds in a sample between the imbibition of seeds and the first sign of germination [43]. mean germination time increased with salinity stress. However, in present study, the mean germination time of water spinach decreased significantly with increasing $\mathrm{NaCl}$ concentration. Seeds of water spinach treated in $75 \mathrm{mM} \mathrm{NaCl}$ treatment experienced the lowest mean germination time. It means that seeds of water spinach have develop tolerance and germinate under high salinity. The seeds of water spinach are still capable to germinate if detrimental effect of salinity is not severe during dormancy period. This is contradicting to the findings of in mango, gasspea and dekoko which showed increasing mean germination time as the salinity level increases [44,45].

\subsection{Effect of Salinity on Seed Vigor}

As the salinity level increases, the general trend of seed vigor of water spinach was associated with significant $(p<0.05)$ decrease as shown in Table 2. Seeds of water spinach treated under control treatment presented the best seed performance while the lowest seed vigor was experienced by seeds treated under $75 \mathrm{mM} \mathrm{NaCl}$ solution. Seed vigor is a 
Table 2. Impact of salinity stress on germination properties of water spinach. Values are mean \pm standard error of mean of fifteen replicates $(N=15)$. Superscripts within the means of each column $(a-b)$ with different letters indicate significant differences among the means (Duncan's Multiple Range Test, $p<0.05$ )

\begin{tabular}{|c|c|c|c|c|c|c|}
\hline $\begin{array}{l}\text { Salt concentration } \\
(\mathrm{mM})\end{array}$ & $\begin{array}{l}\text { Water uptake } \\
\text { percentage (\%) }\end{array}$ & $\begin{array}{l}\text { Germination } \\
\text { percentage (\%) }\end{array}$ & Germination index & $\begin{array}{l}\text { Mean germination } \\
\text { time }\end{array}$ & Seed vigor & $\begin{array}{l}\text { Seedling height } \\
\text { reduction }(\mathrm{cm})\end{array}$ \\
\hline 0 & $76.22 \pm 2.68 a$ & $80.00 \pm 4.14 a b$ & $0.80 \pm 0.04 a b$ & $3.86 \pm 0.14 a$ & $4.78 \pm 0.49 a$ & $0.00 \pm 0.00 c$ \\
\hline 25 & $71.14 \pm 2.90 a b$ & $84.67 \pm 3.36 a$ & $0.85 \pm 0.03 a$ & $3.63 \pm 0.15 a b$ & $4.34 \pm 0.23 a b$ & $10.89 \pm 3.30 b c$ \\
\hline 50 & $66.74 \pm 3.71 \mathrm{ab}$ & $77.33 \pm 3.16 a b$ & $0.77 \pm 0.03 a b$ & $3.36 \pm 0.15 b c$ & $3.70 \pm 0.22 b c$ & $14.57 \pm 4.49 b$ \\
\hline 75 & $62.36 \pm 4.53 b$ & $72.67 \pm 4.19 b$ & $0.73 \pm 0.04 b$ & $3.09 \pm 0.17 c$ & $2.84 \pm 0.19 c$ & $25.88 \pm 5.33 a$ \\
\hline
\end{tabular}

Table 3. Impact of salinity on hypocotyl length, radical length, seedling biomass, total phenolics and total flavonoids of water spinach. Values are mean \pm standard error of mean of fifteen replicates $(N=15)$. Superscripts within the means of each column $(a-b)$ with different letters indicate significant differences among the means (Duncan's Multiple Range Test, $p<0.05$ )

\begin{tabular}{|c|c|c|c|c|c|c|}
\hline $\begin{array}{l}\text { Salt concentration } \\
(\mathrm{mM})\end{array}$ & $\begin{array}{l}\text { Hypocotyl length } \\
\text { (cm) }\end{array}$ & $\begin{array}{l}\text { Radicle length } \\
\text { (cm) }\end{array}$ & $\begin{array}{l}\text { Seedling } \\
\text { biomass }(g)\end{array}$ & Salt tolerance & $\begin{array}{l}\text { Total phenolic content } \\
\text { (mg GAE/g dry weight) }\end{array}$ & $\begin{array}{l}\text { Total flavonoid content } \\
\text { (mg rutin/g dry weight) }\end{array}$ \\
\hline 0 & $3.31 \pm 0.14 a$ & $2.79 \pm 0.15 a$ & $0.048 \pm 0.003 a$ & $100.00 \pm 0.00 a$ & $0.82 \pm 0.19 d$ & $0.31 \pm 0.06 d$ \\
\hline 25 & $2.90 \pm 0.14 b$ & $2.28 \pm 0.09 b$ & $0.050 \pm 0.003 a$ & $137.69 \pm 29.28 a$ & $1.41 \pm 0.08 c$ & $0.83 \pm 0.05 c$ \\
\hline 50 & $2.69 \pm 0.12 b$ & $2.09 \pm 0.07 b c$ & $0.056 \pm 0.003 a$ & $161.11 \pm 35.73 a$ & $2.05 \pm 0.10 b$ & $1.29 \pm 0.07 b$ \\
\hline 75 & $2.05 \pm 0.10 c$ & $1.86 \pm 0.06 c$ & $0.046 \pm 0.002 a$ & $194.06 \pm 51.54 a$ & $2.65 \pm 0.12 a$ & $1.57 \pm 0.13 a$ \\
\hline
\end{tabular}


vital index for seed quality that particularly determines the potential for rapid and uniform emergence of plants. High seed vigor is aligned with potential of increasing growth and productivity agricultural productivity. Seed weight and seed nutrient content gives impact to plant growth at seedling period [46,47]. Earlier studies done to showed a close relationship between seed size or seed weight and early vigor in rice which reveals that rice seed with thin hull and large embryo are preferable for seed vigor [48]. In the present study, Table 2 showed that the vigor of water spinach seeds decreased relative to increasing salinity. Similarly, the decline in seed vigor of melon, desert gourd as the salt concentration increases [49].

\subsection{Effect of Salinity on Seedling Height Reduction}

The seedling height reduction of water spinach seedlings were observed to have a linear relationship with increasing salinity level. The result in Table 2 shows that the seedling height reduction was significantly difference at $(p<0.05)$. Moreover, the seedling height reduction in water spinach declined in all salt treatments due to increasing salinity level. The highest values of seedling height reduction were observed in seeds treated under $75 \mathrm{mM} \mathrm{NaCl}$ solution. There was no much differences among seedlings treated under control treatment and $25 \mathrm{mM} \mathrm{NaCl}$ treatment. However, seedlings treated in higher salinity which is $50 \mathrm{mM}$ and $75 \mathrm{mM} \mathrm{NaCl}$ treatment experienced stunted growth and reduced in length. Most of the seedlings in 75 $\mathrm{mM} \mathrm{NaCl}$ treatment were shrunk and the leaves incompletely developed. Salt stress had significant effects on seedling height reduction. Seedling height reduction in most crop plants grown in saline environments is a common observation [50]. Plant cells usually experienced dehydration and shrink moments after introduced to salinity however their original volume is recovered after few hours [51]. The toxic effects in high salt concentration eventually cause plant to experienced water stress due to an increase in osmotic potential in the rooting medium. The current study revealed that the seedling height reduction of water spinach is significantly increased relative to increasing salinity level. Those seeds treated under $75 \mathrm{mM} \mathrm{NaCl}$ solution has the shortest seedling height as compared to control. This result indicates that high salinity suppresses the early seedling growth of water spinach. The reduction in cell elongation and cell division that eventually leads to slower leaf appearance and leaf size greatly caused by salinity [32].

\subsection{Effect of Salinity on Hypocotyl and Radicle Length}

Table 3 shows that both hypocotyl and radicle length of water spinach seedlings declined significantly at $(p<0.05)$ with increasing salinity level. The result indicates that high salt concentrations negatively affected the length of hypocotyl and radicle of water spinach seedlings as compared to control. The longest hypocotyl and radicle length were experienced by seeds treated under control treatment whereas seeds treated under $75 \mathrm{mM} \mathrm{NaCl}$ solution has the shortest hypocotyl and radicle length. The hypocotyl length and radicle length also reduced with increasing salinity. In present study, the result in Table 3 shows radicle of water spinach experienced more reduction in length compared to hypocotyl. Radicle elongation is more sensitive than hypocotyl under salt stress as it is the first organ facing the injurious effect of salinity. After the plant is introduced to salinization, osmotic stress begins outside the radicle that consequently leads to changes in cell-water relations. Sodium ions are found abundantly in roots while chloride ions mostly concentrated in shoots [52]. Generally, water cannot carry most of the water-soluble nutrients to the root as the osmotic pressure declined at the germination atmosphere [53]. This is similar with the finding in chick pea seedlings [54]. The gradual decrease in hypocotyl of water spinach seedlings may be caused by inhibitory effect of $\mathrm{NaCl}$ salt in hypocotyl growth similar to the finding in five halophytes [55]. Therefore, salinity had a deleterious effect and the reduction of seedling growth in high salinity may be caused by lower absorption of salt component by seed and also germination process is less responsive to high tissue sodium concentrations than early seedling growth.

\subsection{Effect of Salinity on Seedling Biomass}

The result in Table 3 showed inconsistent values of seedling biomass of water spinach with increasing salinity level. There was no significant difference at $(p<0.05)$ recorded for seedling biomass at all salt treatments. The biomass values marked a slight increment from $0 \mathrm{mM}$ to $50 \mathrm{mM}$ salinity and followed by a decline at 75 $\mathrm{mM}$ salinity. The highest seedling biomass was obtained from the seeds treated under $50 \mathrm{mM}$ 
salinity while the least values obtained from the seeds treated under $75 \mathrm{mM}$ salinity. Water spinach seedlings in present study showed inconsistent values of biomass. This is conflicting with the finding in wheat cultivar which showed reduction in seedling biomass at salt concentration increased [56]. Such reduction in biomass is related with enlarging and injuring of hypocotyls and less or slow mobilization of reserve foods. Salinity consist of both osmotic and specific ionic effects on seedling growth. The metabolism of plants is negatively affected by the toxic ion accumulation particularly $\mathrm{Na}^{+}$and $\mathrm{Cl}^{-}$. The uptake of crucial nutrients such as phosphorus $(\mathrm{P})$ and potassium $(\mathrm{K})$ is restricted by high salt concentrations which in turn influence seedling growth [57]. In order to adapt with saline conditions, plants exhibit the ability to prevent the influx of $\mathrm{Na}^{+}$from the roots to the leaves as high amount of sodium could affect nutrient balance and osmotic regulation which eventually causes specific ion toxicity. Osmotic effect resulting from high salinity cause plant inefficiency to absorb water as homeostasis in plant's water status negatively interrupted [58]. This is explained that there where excessively high accumulation of $\mathrm{Na}^{+}$ions in saline environments reduces plant water potential which cause plant cells unable to retrieve the turgidity and thus inhibits plant growth $[59,60]$.

\subsection{Effect of Salinity on Salt Tolerance}

Salt tolerance is frequently studied by adding $\mathrm{NaCl}$ to the growth medium of plant in order to induce the salt stress [61]. The tolerance of water spinach seeds towards salinity was studied using different level $\mathrm{NaCl}$ solution as shown in Table 3. The result shows that water spinach seeds were tolerant in all salinity level. Salt tolerance of water spinach seeds has linear relationship with increasing salt concentrations. However, the values of salt tolerance increased nonsignificantly $(p<0.05)$ in all salt treatments as compared to control. Salt tolerance is commonly evaluated as the percentage of biomass production in saline treatment compared to control condition over a continuous period of time. Each crop plants have different responses towards salinity during germination stage. Water spinach is considered as halophyte or salttolerant plant that could withstand salinity. Work reported that New Zealand spinach has higher salt tolerance compared to water spinach as the growth of New Zealand spinach increased under salt stress [39]. In the present study, salt tolerance of water spinach increased as well as the salinity level increases. This indicates that water spinach is a salt-tolerant species and capable to germinate under saline conditions. Salt tolerance screening at germination period portray little basis for the future assessment of crop salt tolerance as most of germination studies are organized in laboratory with Petridish like containers moisten with solution of various salinity levels [32]. The crop plants that exhibit salt tolerant mechanism during germination stage could turned out to be saltsensitive during vegetative stage [23].

\subsection{Effect of Salinity on Total Phenolic Content (mg GAE/g Dry Weight) and Total Flavonoid Content (mg rutin/g Dry Weight)}

The results in Table 3 shows that total phenolic content and total flavonoid content under all salt concentrations were directly related with increasing salinity level. The values of total phenolic content and total flavonoid content were significantly difference at $(p<0.05)$ relative to the control. Water spinach seedlings were observed to contain more phenolic contents compared to flavonoids. Seeds treated under $75 \mathrm{mM} \mathrm{NaCl}$ concentration has the highest values for both total phenolic and total flavonoid contents as compared to other $\mathrm{NaCl}$ concentrations. Phenolic compounds are vital components of many crops including fruits and vegetables where it contributes color, flavor and sensory properties and also possess important effects on oxidative stability. Generally, phenolic compound is grouped into different classes which is flavonoids and non-flavonoids. Total phenolic content and total flavonoid content of water spinach seedlings in present study are significantly decreased relative with increasing salinity. This is conflicting with the finding in rapeseed where the total phenolic content increased with increasing salinity expressed based on dry weight basis [62]. A study done on artichoke leaves also showed an increase in total phenolic and flavonoids content as salinity increases [63]. However, findings in radish and broccoli showed a decrease of total phenolic content in sprouts at increasing salinity but expressed based on fresh weight basis [64]. Eventually, the total flavonoids content reduced at higher salinity levels. Increment in total phenolic content relative to salinity is one of the responds of seedlings to encounter adverse effects of salinity during germination period [62]. Plants deflects carbohydrates synthesis to produce secondary metabolites. The uptake of phosphorus and 
potassium which are known as main substances of secondary metabolites such as polyphenols decreases at higher salt concentration [65].

\section{CONCLUSION}

Salt stress through advancement of osmotic pressure adversely affects the germination and early seedling growth of water spinach. High salinity level causes reduction in water uptake percentage, seed vigor, total phenolic content, total flavonoid content and mean germination time of the seeds. Seeds of water spinach develop tolerance and encounter the germination delay in high salinity throughout this experiment. Germination percentage and germination index reduced non-significantly with increasing salinity and the result showed seeds treated under 25 $\mathrm{mM} \mathrm{NaCl}$ solution experienced the highest values for both parameters. Apart from that, seedling biomass and relative injury rate showed inconsistent values relative to increasing salinity. Seedling height reduction, hypocotyl length and radicle length were negatively affected by increasing $\mathrm{NaCl}$ concentrations. Salt tolerance of water spinach increased non-significantly with increasing salinity as the seedlings established tolerance during early seedling growth.

\section{COMPETING INTERESTS}

Authors have declared that no competing interests exist.

\section{REFERENCES}

1. Göthberg A, Greger M, Bengtsson BE. Accumulation of heavy metals in water spinach (Ipomoea aquatica) cultivated in the Bangkok region, Thailand. Environmental Toxicology and Chemistry. 2002;21(9):1934-1939.

2. Prasad KN, Prasad MS, Shivamurthy GR, Aradhya SM. Callus induction from Ipomoea aquatica Forsk. leaf and its antioxidant activity. Indian Journal of Biotechnology. 2006;5(1):107-111.

3. Chauhan H, Singh J, Sharma D. Genetic variability and heritability estimation in water spinach (Ipomoea aquatica Forsk.) Genotypes. Int. J. Curr. Microbiol. App. Sci. 2017;6(9):3018-3024.

4. Prasad KN, Divakar S, Shivamurthy GR, Aradhya SM. Isolation of a free radical-scavenging antioxidant from water spinach (Ipomoea aquatica Forssk). Journal of the Science of Food and
Agriculture. 2005;85(9):1461-1468.

5. Doka GI, Tigni SE, Yagi S. Nutritional composition and antioxidant properties of Ipomoea aquatica (Forsek) leaves. J. For. Prod. Industries. 2014;3:204-210.

6. Ors S, Suarez DL. Spinach biomass yield and physiological response to interactive salinity and water stress. Agricultural Water Management. 2017;190:31-41.

7. Shabala S, Munns R. Salinity stress: Physiological constraints and adaptive mechanisms. In S. Shabala, N. Farrar, G. Spearing, A. Lainsbury, \& F. Chippendale (Eds.). Plant Stress Physiology. CAB International. 2012;59-93.

8. Tanji KK, Wallender WW. Nature and extent of agricultural salinity and sodicity. In Wallender, W.W., Tanji, K.K. (Eds.), Agricultural Salinity Assessment and Management. ASCE, Reston, VA, USA. 2012;10-25.

9. Rengasamy P. Transient salinity and subsoil constraints to dryland farming in Australian sodic soils: An overview. Australian Journal of Experimental Agriculture. 2002;42(3):351-361.

10. Aydinşakir $K$, Büyüktaş $D$, Nazmi DiNÇ, Karaca C. Impact of salinity stress on growing, seedling development and water consumption of peanut (Arachis hypogaea cv. NC-7). Mediterranean Agricultural Sciences. 2015;28(2):78-84.

11. Parihar $P$, Singh $S$, Singh $R$, Singh VP, Prasad SM. Effect of salinity stress on plants and its tolerance strategies: A review. Environmental Science and Pollution Research. 2015;22(6):4056-4075.

12. Hassen A, Maher S, Cherif H. Effect of salt stress $(\mathrm{NaCl})$ on germination and early seedling parameters of three pepper cultivars (Capsicum annuum L.). Journal of Stress Physiology \& Biochemistry. 2014;10(1).

13. Parihar $P$, Singh $S$, Singh $R$, Singh VP, Prasad SM. Effect of salinity stress on plants and its tolerance strategies: A review. Environmental Science and Pollution Research. 2015;22(6):4056-4075.

14. Gul B, Ansari R, Flowers TJ, Khan MA. Germination strategies of halophyte seeds under salinity. Environmental and Experimental Botany. 2013;92:4-18.

15. Dantas BF, Ribeiro LDS, Aragão CA. Germination, initial growth and cotyledon protein content of bean cultivars under salinity stress. Revista Brasileira de Sementes. 2007;29(2):106-110. 
16. Hassen A, Maher S, Cherif $\mathrm{H}$. Effect of salt stress $(\mathrm{NaCl})$ on germination and early seedling parameters of three pepper cultivars (Capsicum annuum L.). Journal of Stress Physiology \& Biochemistry. 2014;10(1).

17. Olayinka BU, Ayanduro ET, Abdulrahaman $A A$, Etejere EO. Effects of salinity and ethylenediamine tetra acetic acid (edta) on the germination of tomato (Solanum lycopersicum L.) seeds. Science World Journal. 2016;11(4):1-3.

18. Arias $C$, Serrat $X$, Moysset L, Perissé $P$, Nogués $S$. Morpho-physiological responses of alamo switchgrass during germination and early seedling stage under salinity or water stress conditions. BioEnergy Research. 2018;11(3):677-688.

19. Gairola KC, Nautiyal AR, Dwivedi AK. Effect of temperatures and germination media on seed germination of Jatropha curcas L. Advances in Bioresearch. 2011;2(2):66-71.

20. Han Z, Ku L, Zhang Z, Zhang J, Guo S, Liu $H$, Dong L. QTLs for seed vigor-related traits identified in maize seeds germinated under artificial aging conditions. PloS one. 2014;9(3):e92535.

21. Arias $C$, Serrat $X$, Moysset L, Perissé $P$, Nogués S. Morpho-physiological responses of alamo switchgrass during germination and early seedling stage under salinity or water stress conditions. BioEnergy Research. 2018;11(3):677-688.

22. Tsegay BA, Gebreslassie B. The effect of salinity $(\mathrm{NaCl})$ on germination and early seedling growth of Lathyrus sativus and Pisum sativum var. abyssinicum. African Journal of Plant Science. 2014;8(5):225231.

23. Morris B, Charles S, Son S. Legumes. Encyclopedia of Food and Culture. 2003;3:1-2.

24. Nimbolkar PK, Kurian RM, Upreti KK, Laxman RH, Varalakshmi LR. Seed germination and seedling growth responses of polyembryonic mango (Mangifera indica L.) genotypes to salinity stress. International Journal of Chemical Studies. 2018;6(2):3641-3648.

25. Kaymakanova M. Effect of salinity on germination and seed physiology in bean (Phaseolus vulgaris L.). Biotechnology and Biotechnological Equipment. 2009; 23(Sup 1):326-329.

26. Baba SA, Malik SA. Determination of total phenolic and flavonoid content, antimicrobial and antioxidant activity of a root extract of Arisaema jacquemontii Blume. Journal of Taibah University for Science. 2015;9(4):449-454.

27. Shukla S, Mehta A. Antioxidant, total phenolics and total flavonoid content of the aqueous extract of Caesalpinia bonducella Seeds. Chiang Mai Journal of Science. 2017;44(3):929-938.

28. Tsegay BA, Gebreslassie B. The effect of salinity $(\mathrm{NaCl})$ on germination and early seedling growth of Lathyrus sativus and Pisum sativum var. abyssinicum. African Journal of Plant Science. 2014;8(5):225231.

29. Deivanai S, Xavier R, Vinod V, Timalata K, Lim OF. Role of exogenous proline in ameliorating salt stress at early stage in two rice cultivars. Journal of Stress Physiology \& Biochemistry. 2011;7(4):157174.

30. Qados AMA. Effect of salt stress on plant growth and metabolism of bean plant Vicia faba (L.). Journal of the Saudi Society of Agricultural Sciences. 2011;10(1):715.

31. Kalhori N, Ying T, Nulit R, Sahebi M, Abiri $\mathrm{R}$, Atabaki N. Effect of four different salts on seed germination and morphological effect of four different salts on seed germination and morphological characteristics of Oryza sativa L. CV. MR219. International Journal of Advanced Research in Botany. 2018;4(1):29-45.

32. Jouyban $Z$. The effects of salt stress on plant growth. Technical Journal of Engineering and Applied Sciences. 2012;2(1):7-10.

33. Hameed A, Rasheed A, Gul B, Khan MA. Salinity inhibits seed germination of perennial halophytes Limonium stocksii and Suaeda fruticosa by reducing water uptake and ascorbate dependent antioxidant system. Environmental and Experimental Botany. 2014;107:32-38.

34. Gul B, Ansari R, Flowers TJ, Khan MA. Germination strategies of halophyte seeds under salinity. Environmental and Experimental Botany. 2013;92:4-18.

35. Sarker A, Hossain MI, Kashem MA. Salinity $(\mathrm{NaCl})$ tolerance of four vegetable crops during germination and early seedling growth. Int. J. Latest Res. Sci. Technol. 2014;3(1):91-95.

36. Pradheeban L, Nissanka NAASP, Suriyagoda LDB. Clustering of rice (Oryza sativa L.) varieties cultivated in Jaffna 
District of Sri Lanka based on salt tolerance during germination and seedling stages. Tropical Agricultural Research. 2014;25(3):358-375.

37. Moghaieb RE, Saneoka H, Fujita K. Effect of salinity on osmotic adjustment, glycinebetaine accumulation and the betaine aldehyde dehydrogenase gene expression in two halophytic plants, Salicornia europaea and Suaeda maritima. Plant Science. 2004;166(5):1345-1349.

38. Yousif BS, Nguyen NT, Fukuda YASUKO, Hakata HIROAKI, Okamoto Y, Masaoka YOSHIKUNI, Saneoka H. Effect of salinity on growth, mineral composition, photosynthesis and water relations of two vegetable crops; New Zealand spinach (Tetragonia tetragonioides) and water spinach (Ipomoea aquatica). Int J Agric Biol. 2010;12(2):211-216.

39. Fuller MP, Hamza JH, Rihan HZ, Al-Issawi M. Germination of primed seed under $\mathrm{NaCl}$ stress in wheat. ISRN Botany; 2012.

40. Tsegay BA, Gebreslassie B. The effect of salinity $(\mathrm{NaCl})$ on germination and early seedling growth of Lathyrus sativus and Pisum sativum var. abyssinicum. African Journal of Plant Science. 2014;8(5):225231.

41. Khayatnezhad M, Gholamin R. Effects of salt stress levels on five maize (Zea mays L.) cultivars at germination stage. African Journal of Biotechnology. 2011;10(60): 12909-12915.

42. Demir I, Ermis S, Mavi K, Matthews S. Mean germination time of pepper seed lots (Capsicum annuum L.) predicts size and uniformity of seedlings in germination tests and transplant modules. Seed Science and Technology. 2008;36(1):21-30.

43. Nimbolkar PK, Kurian RM, Upreti KK, Laxman RH, Varalakshmi LR. Seed germination and seedling growth responses of polyembryonic mango (Mangifera indica L.) genotypes to salinity stress. International Journal of Chemical Studies. 2018;6(2):3641-3648.

44. Tsegay BA, Gebreslassie B. The effect of salinity $(\mathrm{NaCl})$ on germination and early seedling growth of Lathyrus sativus and Pisum sativum var. abyssinicum. African Journal of Plant Science. 2014;8(5):225231.

45. Haileselasie TH. The effect of salinity $(\mathrm{NaCl})$ on germination of selected grass pea (Lathyrus sativus I.) landraces of
Tigray. Asian Journal of Agricultural Sciences. 2012;4(2):96-101.

46. Wen D, Hou H, Meng A, Meng J, Xie L, Zhang C. Rapid evaluation of seed vigor by the absolute content of protein in seed within the same crop. Scientific Reports. 2018;8(1):5569.

47. Huang $M$, Zhang $R$, Chen J, Cao F, Jiang L, Zou Y. Morphological and physiological traits of seeds and seedlings in two rice cultivars with contrasting early vigor. Plant Production Science. 2017;20(1):95101.

48. Saberi M, Gharmakhe HN, Heshmati G, Barani $H$, Shahriari A. Effects of different drought and salinity levels on seed germination of Citrullus colocynthis. Ecopersia. 2017;5(3):1903-1917.

49. Hakim MA, Juraimi AS, Begum M, Hanafi MM, Ismail MR, Selamat A. Effect of salt stress on germination and early seedling growth of rice (Oryza sativa L.). African Journal of Biotechnology. 2010;9(13): 1911-1918.

50. Läuchli A, Grattan SR. Plant growth and development under salinity stress. In Advances in molecular breeding toward drought and salt tolerant crops. Springer, Dordrecht. 2007;1-32.

51. Afzali SF, Shariatmadari H, Hajabbasi MA. Sodium chloride effects on seed germination, growth and ion concentration in chamomile (Matricaria chamomilla). Iran Agricultural Research. 2011;29(2):107118.

52. Goraghani S, Reza H, Heidary GA, Solaimani Sardo M. Effects of salinity and drought stresses on seed germination and seedling growth of desert wheatgrass Agropyron desertorum. Journal of Rangeland Science. 2013;4(1):14-22.

53. Gao WR, Wang XS, Liu QY, Peng $H$, Chen C, Li JG, Ma H. Comparative analysis of ESTs in response to drought stress in chickpea (C. arietinum L.). Biochemical and Biophysical Research Communications. 2008;376(3):578-583.

54. Keiffer $\mathrm{CH}$, Ungar IA. The effect of extended exposure to hypersaline conditions on the germination of five inland halophyte species. American Journal of Botany. 1997;84(1):104-111.

55. Rahman M, Soomro UA, Haq MZU, Gul S. Effects of $\mathrm{NaCl}$ salinity on wheat (Triticum aestivum L.) cultivars. World Journal of Agricultural Sciences. 2008;4(3):398-403. 
56. Nasim M, Qureshi R, Aziz T, Saqib M, Nawaz S, Sahi ST, Pervaiz S. Growth and ionic composition of salt stressed Eucalyptus camaldulensis and Eucalyptus teretcornis. Pakistan Journal of Botany. 2008;40(2):799-805.

57. Nordin MN, Che Lah MK, Jahan MS. Effects of different salinity levels on rice production. Australian Journal of Basic and Applied Sciences. 2015;9(5):524-530.

58. Ologundudu AF, Adelusi AA, Akinwale RO. Effect of salt stress on germination and growth parameters of rice. Notulae Scientia Biologicae. 2014;6(2):237.

59. Amirjani MR. Effect of $\mathrm{NaCl}$ on some physiological parameters of rice. European Journal of Biological Sciences. 2010;3(1): 6-16.

60. Kumar V, Khare T. Differential growth and yield responses of salt-tolerant and susceptible rice cultivars to individual $\left(\mathrm{Na}^{+}\right.$ and $\mathrm{Cl}^{-}$) and additive stress effects of $\mathrm{NaCl}$. Acta Physiologiae Plantarum. 2016;38(7):170.

61. Falcinelli B, Sileoni V, Marconi O, Perretti G, Quinet M, Lutts S, Benincasa P.
Germination under moderate salinity increases phenolic content and antioxidant activity in rapeseed (Brassica napus var oleifera Del.) sprouts. Molecules. 2017;22(8):1377.

62. Rezazadeh A, Ghasemnezhad A, Barani $M$, Telmadarrehei $T$. Effect of salinity on phenolic composition and antioxidant activity of artichoke (Cynara scolymus L.) leaves. Res J Med Plant. 2012;6:245-252.

63. Yuan G, Wang X, Guo R, Wang Q. Effect of salt stress on phenolic compounds, glucosinolates, myrosinase and antioxidant activity in radish sprouts. Food Chemistry. 2010;121(4):1014-1019.

64. Guo L, Yang R, Wang Z, Guo Q, Gu Z. Effect of $\mathrm{NaCl}$ stress on health-promoting compounds and antioxidant activity in the sprouts of three broccoli cultivars. International Journal of Food Sciences and Nutrition. 2014;65(4):476-481.

65. Wong CC, Li HB, Cheng KW, Chen F. A systematic survey of antioxidant activity of 30 Chinese medicinal plants using the ferric reducing antioxidant power assay. Food Chemistry. 2006;97(4):705-711.

(c) 2019 Ibrahim et al.; This is an Open Access article distributed under the terms of the Creative Commons Attribution License (http://creativecommons.org/licenses/by/4.0), which permits unrestricted use, distribution, and reproduction in any medium, provided the original work is properly cited.

Peer-review history:

The peer review history for this paper can be accessed here: http://www.sdiarticle3.com/review-history/47891 